\title{
KEPUASAN KERJA GENERASI X DAN GENERASI Y TERHADAP KOMITMEN KERJA DI BANK MANDIRI PALEMBANG
}

\author{
Dwi Oktariani ${ }^{*}$, Aida Vitayala S Hubeis ${ }^{* *}$, dan Dadang Sukandar $\left.{ }^{* * *}\right)$ \\ *) Sekolah Bisnis, Institut Pertanian Bogor \\ Jl. Raya Pajajaran, Bogor 16151 \\ **) Departemen Komunikasi dan Pengembangan Masyarakat, Fakultas Ekonomi dan Manajemen, Institut Pertanian Bogor \\ Jl. Kamper Kampus IPB Darmaga, Bogor 16680 \\ ${ }^{* * *)}$ Departemen Gizi Masyarakat, Fakultas Ekonomi dan Manajemen, Institut Pertanian Bogor \\ Jl. Kamper Kampus IPB Darmaga, Bogor 16680
}

\begin{abstract}
The great number of Y generation who desires flexible working hours, demands creativity and give them the opportunity to posses the impact to the company is the current phenomena. This is the challenge for the older generation to survive in this era of high-tic globalization. The objectives of the research are to define the working expectation characteristic and to analyze the characteristic features of the $X$ and $Y$ generation to find out the working satisfaction dominant aspect in the company. The method used in this research is multiple linear regressions. The result shows that the numbers of respondent variable from both generations have different individual characters therefore the level of satisfaction for each generation also differs in terms of age, gender, salary, and length of working time. The X generation is more committed in working compared to Y generation. The employees' work satisfaction shows the feeling and attitude towards working. Therefore the company could observe and fulfill the employees' expectation in many aspects based on the advantages and disadvantages for both generations. By understanding this, in a long term the employees'working satisfaction can be maximized.
\end{abstract}

Keywords: X Xeneration, Y generation, working satisfaction, working commitment, multiple linear regressions

\begin{abstract}
ABSTRAK
Fenomena yang terjadi saat ini adalah banyak dari pekerja yang termasuk dalam generasi $Y$ menginginkan jadwal kerja yang fleksibel, menuntut kreativitas, dan memberikan kesempatan bagi mereka untuk memiliki dampak bagi perusahaan itu sendiri. Itulah yang menjadi tantangan bagi generasi yang lebih tua untuk tetap bertahan di era global yang serba canggih saat ini. Adapun tujuan dari penelitian ini adalah merumuskan karakteristik dalam ekspektasi bekerja dari generasi $X$ dan generasi $Y$ di Indonesia dan menganalisis ciri-ciri dari generasi $X$ dan $Y$ dalam melihat apa yang menjadi hal dominan terhadap kepuasan kerja dari kedua generasi tersebut dalam suatu perusahaan. Analisis data yang digunakan pada penelitian ini adalah analisis regresi linier berganda. Hasil menunjukkan bahwa variabel jumlah responden dari kedua generasi memiliki karakteristik individu yang berbeda sehingga tingkat kepuasan kerja masing-masing generasi berbeda baik dari segi usia, jenis kelamin, gaji dan lama bekerja. Dilihat dari hasil olah data generasi yang memiliki komitmen kerja lebih tinggi antara generasi $X$ dan $Y$ adalah generasi $X$. Kepuasan kerja karyawan dapat diartikan sebagai evaluasi yang menggambarkan seseorang atas perasaan sikapnya dalam bekerja. Sehingga dengan mengetahui kelebihan dan kekurangan dari tiap Generasi yang berbeda dapat menjadi ukuran sampai seberapa jauh perusahaan dapat melihat dan memenui harapan karyawan yang berkaitan dengan berbagai aspek dalam pekerjaan. Dengan mengetahui hal tersebut dapat membantu memaksimalkan kepuasan kerja karyawan dalam jangka panjang.
\end{abstract}

Kata kunci: generasi $X$, generasi $Y$, kepuasan kerja, komitmen kerja, regresi linear berganda

\footnotetext{
${ }^{1}$ Alamat Korespondensi:

Email: dwioktachandra@yahoo.com
} 


\section{PENDAHULUAN}

Karyawan merupakan asset perusahaan yang paling penting. Menurut De Meuse et al. (2010), terdapat empat generasi angkatan kerja dalam perusahaan, yakni (i) matures, lahir antara tahun 1920 hingga 1939; (ii) Boomers, lahir tahun 1940 hingga 1959; (iii) Xers, lahir tahun 1960 hingga 1979; dan (iv) Generation Y atau mellenials yang lahir tahun 1980 hingga akhir tahun 2000. Adapun kompisisi karyawan di perusahaan ini di dominasi oleh generasi X sebanyak $60 \%$, boomers sebesar $20 \%$ dan generasi Y sebesar 20\%. Gargiulo (2012) menyatakan generasi baby boomers akan meninggalkan pekerjaan sehingga generasi Y akan menempati proporsi tenaga kerja terbesar dalam 10 tahun ke depan. Penelitian lainnya dari Kratz (2013) menunjukkan potensi proporsi generasi $Y$ yang semakin meningkat di masa depan. Pada tahun 2014 generasi Y memiliki proporsi 36\% di dunia kerja. Selanjutnya, pada tahun 2020 kemungkinan $46 \%$ generasi $\mathrm{Y}$ mendominasi dunia kerja.

Indonesia akan mengalami kelangkaan tenaga kerja di tahun 2020 terutama. Hal ini bisa disebabkan oleh banyak faktor salah satu diantaranya karena laju ekspansi ekonomi Indonesia akan lebih cepat dibandingkan dengan pertumbuhan ketersediaan sumberdaya manusia yang baik di Indonesia. Pada masa ini, generasi $\mathrm{Y}$ adalah angkatan kerja yang dominan mengisi kebutuhan sumberdaya manusia. Dengan kondisi ketersediaan yang terbatas, manajemen sumberdaya manusia menjadi penting agar perusahaan dapat memastikan kesinambungan ketersediaan sumber daya manusia tersebut dalam mengisi lingkungan kerja yang efektif. Populasi generasi $\mathrm{Y}$ di dalam perusahaan saat ini sudah mencapai 50\%-75\%. Artinya, maka banyak dari perusahaan akan megalami kesulitan untuk mempertahankan para pekerja (Luntungan, 2014).

Generasi Y adalah individu yang lahir pada tahun 19802000 (Meier, Austin, dan Crocker, 2010). Generasi ini lahir di era perkembangan teknologi informasi dan dunia pendidikan sehingga memiliki karakteristik yang berbeda dibandingkan generasi sebelumnya. Misalnya saja, generasi Y lebih memperhatikan aspek work life balance dibandingkan generasi X (Meier, Austin, dan Crocker, 2010). Masing-masing generasi ini memiliki karakteristik yang berbeda. Gen Y akan cenderung kritis saat akan melakukan sesuatu. Fakta bahwa apa yang generasi $\mathrm{Y}$ akan lakukan harus memiliki nilai tambah bagi mereka secara individu sehingga apa yang generasi Y lakukan akan sesuai dengan apa yang mereka harapkan. Menurut Solnet (2008) generasi yang disebut mellenials biasanya akan mengutamakan diri sendiri dan membutuhkan adanya feedback, peghargaan dan pujian yang konstan dari atasan mereka. Generasi Y memiliki harga diri yang tinggi, entrepreneurial dan menginginkan pekerjaan yang memiliki arti sesegera mungkin serta sangat antusias terhadap pekerjaan.

Fenomena yang terjadi saat ini adalah banyak dari pekerja yang termasuk dalam generasi $Y$ menginginkan jadwal kerja yang fleksibel, menuntut kreativitas, dan memberikan kesempatan bagi mereka untuk memiliki dampak bagi perusahaan itu sendiri. Bagi perusahaan yang bergerak di industri perbankan, industri kreatif, telekomunikasi, dan teknologi informasi, kehadiran gen Y bisa dianggap berkah. Cara berpikir generasi ini yang think out of the box menghasilkan ide-ide kreatif yang berguna bagi kemajuan perusahaan. Seperti yang terjadi pada industri perbankan, pada kenyataan nya setiap tahun menerima banyak usulan dari karyawan yang masih muda-muda. Semua aspirasi dan masukan itu ditampung, bahkan sampai ke pusat. Bank Mandiri menganjurkan semua karyawan untuk berpikir kreatif. Bank Mandiri hebat bukan karena pemimpinnya, tetapi karena mau mendengarkan ideide karyawan. Oleh karena itu, sepantasnya kehadiran gen Y menjadi tantangan berat bagi praktisi human capital management bagaimana memfasilitasi anakanak muda ini agar energi mereka tersalurkan untuk memajukan perusahaan.

Kehadiran gen $\mathrm{Y}$ di perusahaan bahkan mampu menggeser paradigma yang selama ini dianut generasi $\mathrm{X}$. Jika dahulu atasan selalu lebih tua dari bawahan karena perusahaan menerapkan sistem senioritas, sekarang tidak demikian. Karyawan-karyawan berusia muda di bawah 35 tahun banyak yang sudah menduduki posisi tinggi di perusahaan. Itulah yang menjadi tantangan bagi generasi yang lebih tua untuk tetap bertahan di era global yang serba canggih saat ini. Adanya kebutuhan profesionalisme dalam pengelolaan manajemen dan operasional suatu perusahaan maka memerlukan kompetensi dari para tenaga kerja baik yang sudah berpengalaman atau masih mencari pengalaman.

Dalam penelitian ini, peneliti ingin fokus pada kedua generasi, mengingat tantangan yang akan dihadapi perusahaan di tahun yang akan datang akan semakin berat. Generasi Y menjadi harapan bagi perusahaan karena jumlah dari generasi $\mathrm{Y}$ semakin meningkat 
jumlahnya dari ahun ke tahun. Mengingat kurang nya defenisi mengenai karakteristik dan ciri-ciri yang dominan dari tiap generasi maka perlu dilakukan upaya pemahaman keberadaan tiap generasi.

Keberhasilan suatu organisasi tergantung pada kemampuannya, untuk mengelola berbagai macam sumber daya yang dimilikinya, salah satu yang sangat penting yaitu sumber daya manusia.SDM senantiasa melekat pada setiap sumber daya organisasi apapun sebagai faktor penentu keberadaan dan peranannya dalam memberikan kontribusi ke arah pencapaian tujuan organisasi secara efektif dan efisien (Cholil dan Riani, 2003).

Tujuan dalam penelitian ini adalah untuk merumuskan karakteristik dalam ekspektasi bekerja dari generasi $\mathrm{X}$ dan generasi $\mathrm{Y}$ di Indonesia dan juga menganalisis ciri-ciri dari generasi $\mathrm{X}$ danY dalam melihat apa yang menjadi hal dominan terhadap kepuasan kerja dari kedua generasi tersebut dalam suatu perusahaan.

Asumsi yang dibangun dalam penelitian ini adalah bahwa faktor-faktor yang Memengaruhi tingkat kepuasan kerja dari kedua generasi dan cara mereka dalam berkomitmen terhadap pekerjaan mereka dalam suatu perusahaan tergantung dengan dinamika dan perubahan budaya suatu bidang pekerjaan dari setiap generasi. Hal ini sudah berjalan sesuai dengan ekspektasi dari kedua generasi terhadap perusahaan mereka sehingga bagi generasi X mereka akan merasa puas terhadap pekerjaan yang mereka dan memutuskan untuk selalu berkomitmen terhadap perusahaan mereka. Sebaliknya, bagi generasi Y mereka memiliki pertimbangan terhadap faktor apa saja yang membuat mereka memiliki tingkat kepuasan kerja yang tinggi sehingga keinginan untuk pindah dari suatu perusahaan ke perusahaan lain lebih sedikit.

\section{METODE PENELITIAN}

Dalam penelitian ini terdapat dua variabel yang akan diteliti. Kedua variabel penelitian tersebut adalah kepuasan kerja dan komitmen kerja dari kedua generasi, yaitu generasi $\mathrm{X}$ dan Y. Setelah melihat hubungan dan pengaruh dari kepuasan kerja terhadap komitmen kerja maka terdapat beberapa subvariabel independen diantara nya adalah generasi kelahiran (yang diukur dengan usia), gaji, pendidikan terakhir dan jenis kelamin yang juga memiliki pengaruh terhadap komitmen kerja seorang karyawan.
Penelitian ini dilakukan di Bank Mandiri (Kantor Wilayah) Provinsi Sumatera Bagian Selatan. Pemilihan lokasi dilakukan secara sengaja (purposive) dengan berdasarkan pada terdapat banyaknya karyawan yang bekerja, serta pertimbangan adanya kesediaan karyawan yang termasuk dalam golongan usia generasi $\mathrm{X}$ dan generasi $\mathrm{Y}$ yang bekerja di perusahaan tersebut sehingga bisa memberikan informasi dan data yang diperlukan sesuai dengan penelitian. Pengambilan data lapangan dilakukan dalam selama April 2015.

Bank Mandiri Provinsi Sumatera Selatan memiliki jumlah karyawan sebanyak 1370 orang. Responden dipilih dengan metode pengambilan sampel acak sederhana (simple random sampling). Setelah mengetahui jumlah sampel dari keseluruhan jumlah karyawan Bank Mandiri tersebut maka kita akan mengambil contoh sampel populasi nya dengan menggunakan rumus sample size oleh William G. Cochran sebagai berikut:

$$
\eta=\frac{z^{2} \cdot p \cdot q}{1+\frac{1}{N}\left(\frac{z^{2} \cdot p \cdot q}{d^{2}}-1\right)}
$$

keterangan:

$\eta \quad:$ jumlah sampel minimal

$\mathrm{N}$ : ukuran populasi

$\mathrm{Z}$ : tingkat kepercayaan (digunakan 0,90 sehingga nilai $\mathrm{t}=1,64)$

d : tarat kekeliruan (digunakan 0,10)

$\mathrm{p}$ : proporsi dari karakteristik tertentu (golongan generasi)

$\mathrm{q}: 1-\mathrm{p}$

1 : bilangan konstan

Penelitian ini merupakan penelitian untuk melihat dampak kepuasan kerja dari pekerja dalam generasi $\mathrm{X}$ dan generasi $\mathrm{Y}$ berdasarkan gender sebagai proses pengembangan kariernya dan juga komitmen kerjanya di masing-masing instantsi yang terkait. Penelitian ini lebih mementingkan pada informasi yang akan digali untuk mempelajari suatu permasalahan yang ada agar didapat informasi sesuai tujuan sehingga jumlah sampel yang diambil menjadi aspek yang terpenting.

Pengolahan data dilakukan secara manual melalui tabulasi, uji statistic non parametric melalui uji linear berganda untuk melihat pengaruh dari varibel independent dan dependent dengan data nominal. Hal ni dilakukan guna ketepatan, kecepatan proses perhitungan dan kepercayaan hasil pengujian. Regresi 
linear berganda menjadi alat analisis dalam penelitian kali ini karena untuk melihat bagaimana pengaruh dari kepuasan kerja generasi $\mathrm{X}$ dan $\mathrm{Y}$ yang akan Memengaruhi komitmen kerja nya.

Kuesioner yang berisi daftar pertanyaan merupakan wujud nyata dari instrumen penelitian. Instrumentinstrumen yang dibuat untuk mengumpulkan data perlu diuji validitas dan reliabilitasnya terlebih dahulu. Uji validitas dan reliabilitas dilakukan terhadap semua item/ variabel yang nantinya akan digunakan pada analisis komitmen seorang karyawan yang terdiri dari variabel dalam kepuasan kerja dan komitmen kerjanya. Jumlah variabel dalam uji validitas dan reabilitas sebanyak 30 item kuesioner.

Penilaian uji validitas terhadap semua item yang diuji adalah menggunakan nilai $\mathrm{r}$ tabel dan $\mathrm{r}$ hitung itu sendiri. Jika nilai $\mathrm{r}$ hitung $>$ nilai $\mathrm{r}$ table maka item dikatakan valid. Nilai $\mathrm{r}$ table product moment didapatkan dari derajat kebebasan/dk, yakni $\mathrm{dk}=$ $\mathrm{n}-2$, dimana $\mathrm{n}$ adalah jumlah responden dengan menggunakan taruf signifikan 5\%. Jadi, diperoleh nilai $r$ table sebesar 0,374 . Nilai $r$ hitung diperoleh dari nilai item-total-statistic pengolahan data menggunakan program SPSS versi 11,5 yang terdapat pada kolom corrected Item - total Correlation. Jika nilai $\mathrm{r}$ hitung $>$ 0,374 maka item dinyatakan valid.

Instrumen penelitian ini adalah kuesioner atau daftar pertanyaan tertutup menggunakan model skala likert. Skala ini mengukur tingkat persetujuan atau tingkat ketidaksetujuan responden terhadap serangkaian pernyataan yang mengukur suatu objek. Dalam penelitian ini skala likert digunakan untuk mengukur tingkat kepuasan kerja dan komitmen kerja generasi $\mathrm{X}$ dan Y. Skala likert dapat dikategorikan sebagai skala interval. Dalam penelitian ini menggunakan lima kategori pilihan, yaitu Sangat Rendah $(\mathrm{SR})=1$; Rendah $(\mathrm{R})=2$; Netral $(\mathrm{N})=3$; Tinggi $(\mathrm{T})=4$; Sangat Tinggi $(\mathrm{ST})=5$.

Alasan menggunakan lima kategori karena literatur yang sudah ada sebelumnya memang menggunakan lima kategori pilihan yang memungkinkan responden memberikan jawaban atau pilihan pada beberapa kategori sesuai dengan persepsi masing-masing.
Pengaruh dari faktor kepuasan kerja dalam generasi $\mathrm{X}$ dan $\mathrm{Y}$ terhadap komitmen kerja dalam penelitian ini dapat dilihat dengan menggunakan regresi linear berganda maka kedua variabel independent dan dependent dalam penelitian kali ini akan diuji dengan alat SPSS for windows. Secara umum model regresi linear berganda untuk populasi adalah sebagai berikut:

$$
\mathrm{Y}_{1}=\beta_{0}+\beta_{1} \mathrm{x}_{1}+\beta_{2} \mathrm{x}_{2}+\beta_{3} \mathrm{x}_{3}+\beta_{4} \mathrm{x}_{4}+\beta_{5} \mathrm{x}_{5}+\boldsymbol{\varepsilon}
$$

keterangan :

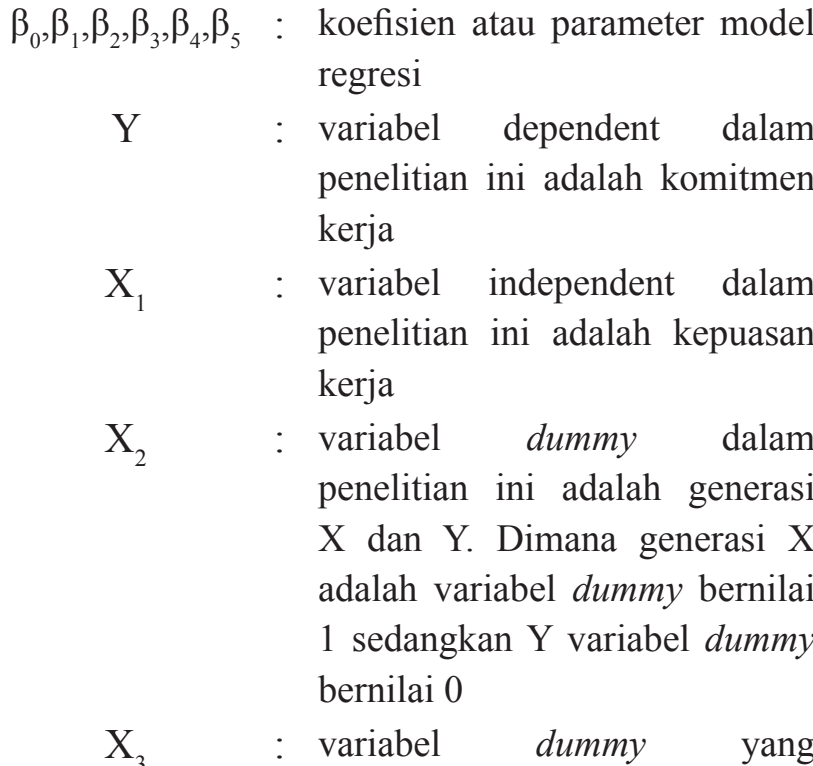
menggambarkan jenis kelamin yaitu laki-laki dan perempuan. Dengan variabel dummy bernilai 0 adalah laki-laki dan variabel dummy 1 adalah perempuan

$\mathrm{X}_{4} \quad$ : variabel dummy dalam penelitian ini adalah keseluruhan gaji karyawan dari laki-laki dan perempuan baik dari generasi $\mathrm{X}$ dan Y. Dengan kriteria dummy bernilai 1 adalah kisaran gaji antara $<1$ jt, bernilai 2 adalah kisaran gaji antara $1-5 \mathrm{jt}$, bernilai 3 adalah kisaran gaji 5-10jt, dan bernilai 4 adalah kisaran gaji antara $>10 \mathrm{jt}$

$\mathrm{X}_{5} \quad$ : variabel dummy yang menggambarkan pendidikan terakhir dari karyawan generasi $\mathrm{X}$ dan $\mathrm{Y}$ dengan kategori SMA yang bernilai 1, D3 yang bernilai 2 , strata 1 yang bernilai 3 , strata 2 yang bernilai 4

$\boldsymbol{\varepsilon}:$ error 
Dalam analisis deskriptif ini penulis akan menggambarkan mengenai karakteristik dari generasi $\mathrm{X}$ dan $\mathrm{Y}$ di Indonesia yang dilihat dari katakteristik individu masing-masing generasi dalam cara mereka bekerja. Dan juga penulis ingin mengambarkan bagaimana kepuasan kerja yang terjadi dari masingmasing generasi di Bank Mandiri. Tujuan deskripsi ini adalah agar pembaca masuk ke dalam masalah pada penelitian dengan hasil yang ditunjukan oleh partisipan yang memberi kesempatan kepada peneliti untuk memahami rasa ketidakpuasan seseorang yang bekerja berdasarkan generasi kelahiran, gender (jenis kelamin), gaji pokok dan pendidikan terakhir. Jadi, sumber utama dari kesimpulan penelitian ini adalah diperolehnya data kualitatis secara tertulis atau tanggapan dalam kuesioner

\section{Hipotesis Penelitian}

Berdasarkan latar belakang, perumusan masalah, tujuan penelitian, manfaat penelitian, tinjauan pustaka serta kerangka pemikiran yang telah dirumuskan sebelumnya maka diperoleh dugaan sementara (hipotesis). Mengacu pada model penelitian yang dipakai oleh penulis maka hipotesis pada penelitian ini adalah sebagai berikut:

1. H0 : Kepuasan kerja tidak berpengaruh terhadap komitmen kerja

H1 : Kepuasan kerja berpengaruh signfikan terhadap komitmen kerja

2. H0 : Generasi kelahiran tidak berpengaruh terhadap komitmen kerja

H1 : Generasi kelahiran berpengaruh siginifikan terhadap komitmen kerja

3. H0 : Jenis Kelamin tidak berpengaruh terhadap komitmen kerja

H1 : Jenis Kelamin berpengaruh siginifikan terhadap komitmen kerja

4. H0 : Gaji Karyawan tidak berpengaruh terhadap komitmen kerja

H1 : GajiKaryawanberpengaruhsiginifikan terhadap komitmen kerja

5. H0 : Pendidikan terakhir tidak berpengaruh terhadap komitmen kerja

H1 : Pendidikan terakhir berpengaruh siginifikan terhadap komitmen kerja

\section{Profil Responden}

Sebaran responden berdasarkan jumlah sampel yang sudah dipilih berdasarkan kriteria dan rumus pengambilan sampel adalah sebanyak 132 orang. Jumlah responden yang dianggap masuk dalam kategori sebagai responden yang bisa dijadikan sebagai sampel adalah 60 orang generasi $\mathrm{X}$ dan 72 orang generasi Y.

Seluruh responden dalam tahap kuesioner memenuhi kriteria yang ditetapkan, yaitu usia kelahiran berdasarkan generasi $\mathrm{X}$ dan $\mathrm{Y}$, berdasarkan jenis kelamin, strata pendidikan, gaji juga dilihat lama bekerja selama lebih dari 3 bulan di Bank Mandiri. Banyaknya responden di Bank Mandiri sendiri menggambarkan bahwa generasi $\mathrm{Y}$ adalah generasi yang menduduki banyak sekali posisi dalam organisasi.

\section{HASIL}

\section{Gambaran Karakteristik Generasi X di Indonesia}

Pada saat generasi X lahir, mereka dibesarkan oleh generasi baby boomer dimana etika kerja generasi ini sangat kuat, kerja keras adalah jalan menuju sukses. Sehingga banyak waktu yang digunakan oleh generasi $\mathrm{X}$ ditempat kerja. Pada umumnya generasi $\mathrm{X}$ yang bekerja akan menggunakan waktu dari pagi hari dan akan pulang ketika hari sudah mulai malam. Pada saat itu pula perubahan dunia terjadi begitu cepat antara lain kemajuan teknologi televisi dan komputer yang begitu cepat sehingga arus informasi dan pengetahuan dunia dapat dengan mudah dilihat.

Dalam bekerja generasi $\mathrm{X}$ memiliki ekspektasi kerja berdasarkan karakteristik yang dimilikinya. Anantatmula (2012) mengatakan bahwa ekspektasi kerja darigenerasi $\mathrm{X}$ adalah cenderung diberikan otoritas dalam pekerjaan, hal ini disebabkan karena dalam bekerja generasi $\mathrm{X}$ tidak memiliki sifat individualis dan mampu bekerja dengan tim. Sehingga hal ini akan memberikan generasi X keterlibatan yang baik dalam pengambilan keputusan. Generasi ini cenderung akan saling mendengarkan satu sama lain karena memiliki rasa profit sharing satu sama lain sebagai rekan kerja. Sehingga pengembangan diri generasi $\mathrm{X}$ dilahirkan dari fasilitas dan lingkungan yang baik dalam perusahaan.

Dibutuhkan kondisi yang tenang dan nyaman dalam lingkungan kerja adalah merupakan karakteristik 
dalam ekspektasi kerja yang dimiliki oleh generasi $\mathrm{X}$, hal ini karena generasi $\mathrm{X}$ memiliki rasa tanggung jawab penuh pada setiap pekerjaan yang telah diberikan oleh perusahaan. Generasi X akan merasa senang dan dihargai oleh perusahaan apabila perusahaan mampu memberikan semacam pengembangan diri dalam bentuk seminar atau training sehingga mereka akan terus melakukan inovasi yang baik bagi individu dan perusahaan dimana mereka bekerja.

Bagi generasi $\mathrm{X}$ hal-hal seperti bonus, gaji dan reward adalah sebagai tanda prestasi kerja yang merupakan hal penting bagi mereka. Karena jika dilihat dari sudut pandang usia yang lebih tua daripada generasi Y maka bagi generasi $\mathrm{X}$ hal semacam materi menjadi faktor utama dalam melakukan pekerjaan. Dalam generasi ini melakukan pekerjaan yang melampaui batas jam kerja seharusnya adalah hal biasa, asalkan setelah itu mereka diberi timbal balik yang sesuai (Zemke et al. 2000).

Generasi $\mathrm{X}$ memiliki kecendurungan yang negatif yang biasanya tidak sebanding dengan generasi $Y$ yaitu kurang nya kepedulian terhadap kemajuan teknologi sehingga generasi $\mathrm{X}$ akan dengan mudahnya dikalahkan oleh generasi $Y$ yang cenderung memiliki ide-ide lebih inovatif dan bersifat global. Karena generasi X hanya akan mengikuti alur perusahaan seperti biasanya dan takut pada perubahan-perubahan yang ditimbulkan oleh kemajuan teknologi dan globalisasi.

Generasi X merupakan generasi yang memiiki komitmen dan loyalitas yang cenderung tinggi terhadap perusahaan dimana mereka bekerja. Sifat kepedulian yang dimiliki oleh generasi $\mathrm{X}$ sebagai bentuk pertanggung jawaban terhadap pekerjaan individu dan feedback terhadap perusahaan menjadikan generasi ini cenderung menduduki jabatan-jabatan penting dalam perusahaan. Bekerja merupakan hal yang sangat penting dan tidak membosankan bagi generasi $\mathrm{X}$ sehingga dibutuhkan sifat yang telaten juga sabar dalam menghadapi semua rutinitas pekerjaan yang diperolehnya. Bahkan generasi $\mathrm{X}$ cenderung lebih memilih pekerjaan dan mengorbankan kepentingan yang bersifat pribadi, hal ini menjadikan generasi $\mathrm{X}$ mejadi contoh yang baik bagi generasi $\mathrm{Y}$ yang bekerja dalam perusahaan yang sama.

\section{Gambaran Karakteristik Generasi Y di Indonesia}

Karakteristik yang dimiliki oleh generasi $\mathrm{Y}$ sangat berbeda atau bertolak belakang dengan generasi $\mathrm{X}$ dalam cara mereka bekerja di suatu perusahaan. Berdasarkan penelitian sebelumnya yang dilakukan oleh Sijabat (2011) adalah sebagian besar memiliki karakteristik yang positif dan negatif. Beberapa diantaranya yang bersifat positif yang dimiliki oleh generasi $\mathrm{Y}$ adalah keperdulian terhadap teknologi baru sesuai dengan perkembangan dunia. Hal ini menyebabkan generasi $\mathrm{Y}$ akan aktif untuk mencoba hal-hal baru dalam bekerja, apabila perusahaan tempat dimana generasi Y bekerja tidak bisa memberikan wadah yang tepat bagi mereka yang cenderung memiliki ide-ide kreatif dan out of the box maka besar kemungkinan generasi $\mathrm{Y}$ akan merasa tidak nyaman dan tidak puas. Generasi Y cenderung tidak takut pada perubahan-perubahan yang terjadi dalam perusahaan, hal ini dinilai sebagai hal yang positif karena generasi Y mampu menghadapi permasalahan yang timbul dalam bekerja, karena kebanyakan dari generasi $\mathrm{Y}$ adalah orang yang pintar dan handal. Hal ini mengakibatkan generasi $\mathrm{Y}$ akan melihat dari sudut pandang yang berbeda dari generasi sebelumnya.

Generasi Y lahir dengan adanya perubahan teknologi dan era globalisasi yang sangat cepat sehingga persaingan yang ditimbulkan dari generasi ini sendiri menimbulkan karakteristik yang negatif. Sugembong dan Sudarmoyo (2007) mengatakan beberapa sifat yang dimiliki oleh generasi $\mathrm{Y}$ yang dinilai tidak baik jika diaplikasikan dalam dunia bekerja adalah sifat individualis. Generasi Y memiliki sifat yang sangat individualis dalam cara berfikir dan bekerja sehingga melahirkan sifat ego sentris, tidak perduli dan cepat bosan. Hal ini akan menimbulkan dampak yang tidak baik baik sesama rekan kerja dan perusahaan. Bagi mereka untuk saling perduli dan memiliki waktu sharing kepada sesame rekan kerja adalah hal yang tidak terlalu penting. Sehingga generasi ini dinilai tidak sabaran dan tidak mempnyai tanggung jawab penuh terhadap pekerjaan mereka.

Generasi Y memiliki kecendrungan yang rendah terhadap komitmen dan loyalitas mereka dalam bekerja, karena sifat mereka yang kurang serius dan menyepelekan pekerjaan mereka. Kembali lagi karena generasi $Y$ cenderung merasa bahwa kecerdasan mereka akan sangat dibutuhkan oleh perusahaan. Oleh karena itu, reward, gaji dan waktu yang fleksibel akan menjadi pertimbangan yang penting bagi mereka untuk tetap bekerja dan berada dalam suatu perusahaan.

Hal-hal yang biasanya dijadikan generasi $\mathrm{Y}$ pertimbangan dalam memiliki komitmen bekerja 
adalah waktu bekerja yang fleksibel, tidak ada penambahan jam kerja yang melebihi dari waktu seharusnya mereka bekerja. Memiliki rekan kerja yang menyenangkan ketika menyelasaikan pekerjaan, tetapi tidak menginginkan keterlibatan dalam hal-hal yang menimbulkan persaingan apabila bekerja sama dengan para generasi $\mathrm{X}$. Bagi generasi $\mathrm{Y}$ diberikan nya waktu luang bagi kehidupan pribadi merupakan hal yang sangat penting, selain hanya masalah pekerjaan dikantor, mereka akan menghargai waktu yang diberikan terhadap hal-hal pribadi karena menyebabkan mereka terlepas dari beban pekerjaan selama bekerja.

Masalah yang seringkali dihadapi oleh generasi $\mathrm{Y}$ adalah sifat adiktif terhadap gadget dan perubahan perkembangan teknologi sehingga cenderung mereka tidak fokus dalam bekerja dan emosi tidak stabil. Hal ini menyebabkan diperlukan nya toleransi yang besar bagi perusahaan mengingat angka generasi $\mathrm{Y}$ akan sangat banyak menduduki posisi-posisi baru dalam perusahaan.

\section{Ciri-ciri Dominan Generasi $\mathbf{X}$ terhadap Kepuasan Kerja di Bank Mandiri}

Karakteristik individu ini juga akan dijadikan dasar guna menganalisis karakteristik responden yang ada, dalam hubungannya dengan kepuasan kerja. Maka peneliti akan melihat juga bagaimana hubungan karakteristik individu generasi $\mathrm{X}$ terhadap kepuasan kerja mereka. Pada Tabel 1 dapat digambarkan bahwa generasi $\mathrm{X}$ secara garis besar memiliki tingkat kepuasan kerja yang tinggi baik dalam karakteristik gaji, usia, jenis kelamin, tingkat pendidikan sehingga menyebabkan generasi $\mathrm{X}$ ingin bekerja lama di Bank Mandiri dan memiliki komitmen yang tinggi.

\section{Ciri-ciri Dominan Generasi Y terhadap Kepuasan kerja di Bank Mandiri}

Karakteristik individu ini juga akan dijadikan dasar guna menganalisis karakteristik responden yang ada, dalam hubungannya dengan kepuasan kerja. Maka peneliti akan melihat juga bagaimana hubungan karakteristik individu generasi $\mathrm{Y}$ terhadap kepuasan kerja mereka. Tabel 2 dapat dijelaskan pada poin satu adalah bahwa responden generasi Y baik laki-laki ataupun perempuan dengan kesamaan perbandingan kepuasan kerja yang diterima memiliki cara pandang dan penilaian yang berbeda untuk memiliki rasa kepuasan kerja.

\section{Kepuasan Kerja Generasi X dan Generasi Y terhadap Komitmen Kerja di Bank Mandiri}

Kepuasan kerja karyawan dapat diartikan sebagai evaluasi yang menggambarkan seseorang atas perasaan sikapnya dalam bekerja. Sehingga dengan mengetahui kelebihan dan kekurangan dari tiap generasi yang berbeda dapat menjadi ukuran sampai seberapa jauh perusahaan dapat melihat dan memenui harapan karyawan yang berkaitan dengan berbagai aspek dalam pekerjaan. Dengan mengetahui hal tersebut dapat membantu memaksimalkan kepuasan kerja karyawan dalam jangka panjang.

Tabel 1. Karakteristik Generasi X

\begin{tabular}{|c|c|}
\hline Laki-laki & Perempuan \\
\hline $\begin{array}{l}\text { Laki-laki biasanya cenderung memiliki tingkat kepuasan } \\
\text { yang lebih rendah dari perempuan (Zefane et al. 2007). }\end{array}$ & $\begin{array}{l}\text { Perempuan cenderung lebih memiliki kepuasan kerja lebih } \\
\text { tinggi dibandingkan dengan laki-laki. }\end{array}$ \\
\hline $\begin{array}{l}\text { Laki-laki akan menemukan kepuasan kerja seiring dengan } \\
\text { meningkat nya level pendidikan yang dimiliki (Franek et al. } \\
\text { 2010). }\end{array}$ & $\begin{array}{l}\text { Perempuan akan tetap menemukan kepuasan kerja nya } \\
\text { meskipun pada waktu mulai bekerja dan masih bekerja } \\
\text { level pendidikan terakhir yang dimilikinya masih sama. }\end{array}$ \\
\hline $\begin{array}{l}\text { Semakin meningkatnya usia yang dimiliki maka akan } \\
\text { semakin meningkat pula kepuasan kerja dari seorang laki- } \\
\text { laki generasi ini. Oleh karena itu, dengan kecendrungan } \\
\text { sifat yang suka bekerja dan mencintai pekerjaannya, } \\
\text { semakin usia mereka bertambah maka akan semaking } \\
\text { menghargai pekerjaan nya (Siu et al. 2006). }\end{array}$ & $\begin{array}{l}\text { Semakin meningkatnya usia dari seorang perempuan } \\
\text { dalam generasi X akan meningkatkan kepuasan kerja yang } \\
\text { dimiliki mereka (Heaney, 2007). }\end{array}$ \\
\hline $\begin{array}{l}\text { Dalam suatu perusahaan biasa nya laki-laki generasi } X \text { akan } \\
\text { menduduki tempat yang tinggi sebagai atasan (Setiawati, } \\
\text { 2007). }\end{array}$ & $\begin{array}{l}\text { Dalam masa bekerja yang dimiliki oleh perempuan generasi } \\
\mathrm{X} \text { biasanya akan menimbulkan kepuasan kerja yang tinggi. } \\
\text { Karena perempuan dalam kategori usia di generasi X sudah } \\
\text { tidak bisa memilih pekerjaan lain dan tidak ingin memilih } \\
\text { pekerjaan lain. }\end{array}$ \\
\hline
\end{tabular}


Tabel 2. Karakteristik Generasi Y

\begin{tabular}{|c|c|}
\hline Laki-laki & Perempuan \\
\hline $\begin{array}{l}\text { Laki-laki memiliki kecenderungan ketidakpuasan bekerja } \\
\text { yang lebih tinggi dibandingkan dengan perempuan di } \\
\text { generasi Y (Suryadi, 2015). }\end{array}$ & $\begin{array}{l}\text { Perempuan cenderung memiliki kepuasan kerja yang } \\
\text { rendah (Miller et al. 2014). }\end{array}$ \\
\hline $\begin{array}{l}\text { Bagi laki-laki generasi } Y \text { cenderung tidak puas dengan } \\
\text { tingkat pendidikan mereka dan menginginkan pendidikan } \\
\text { yang lebih tinggi (Abbas, 2014). }\end{array}$ & $\begin{array}{l}\text { Perempuan pada generasi } Y \text { dari segi tingkat pendidikan } \\
\text { nya cenderung memiliki kepuasan yang rendah (Fernandez, } \\
\text { 2009). }\end{array}$ \\
\hline $\begin{array}{l}\text { Bahwa laki-laki generasi Y tidak puas sehingga mudah saja } \\
\text { bagi mereka untuk berpindah dari satu tempat ke tempat } \\
\text { lain (Baldonado and Spangenburg, 2009). }\end{array}$ & $\begin{array}{l}\text { Perempuan pada generasi Y cenderung akan setia pada } \\
\text { perusahaan tempat mereka bekerja jika espektasi kerja } \\
\text { mereka terpenuhi. }\end{array}$ \\
\hline $\begin{array}{l}\text { Dengan ukuran lama bekerja di Bank Mandiri bisa } \\
\text { digambarkan bahwa generasi Y memiliki komitmen yang } \\
\text { rendah karena selama rentang usia mereka bekerja generasi } \\
\text { Y minimal sudah dua kali berpindah tempat kerja. }\end{array}$ & $\begin{array}{l}\text { Generasi } Y \text { cenderung setia pada organisasi jika ekspektasi } \\
\text { mereka terpenuhi (Dries et al. 2008). }\end{array}$ \\
\hline
\end{tabular}

Berdasarkan rumus sample size dari Cochran maka diperoleh n sebanyak 132 orang, termasuk di dalam nya adalah sebanyak 60 orang dari generasi $\mathrm{X}$ dan sebanyak 72 orang dari generasi Y. Jumlah $\mathrm{N}$ tersebut di dapat dari perhitungan berikut ini:

$$
\eta=\frac{\eta_{0}}{1+\frac{\eta_{0}}{N}}=\frac{0,25 \times 0,25 \times 1.64^{2}}{1+\frac{0.1681}{1370}}=145.4152249
$$

Selanjutnya mencari $\mathrm{n}$ nya menggunakan rumus berikut:

$$
\begin{aligned}
& \eta_{0}=\frac{\rho(1-\rho) t^{2}}{d^{2}}=\frac{0.25(1-0.25) 1.64^{2}}{0.068^{2}} \\
& \eta_{0}=131.4615657 \text { dibulatkan menjadi } 132
\end{aligned}
$$

\section{Keterangan:}

$$
\begin{array}{rlll}
\mathrm{n} & : & \text { jumlah sampel minimal } \\
\mathrm{N} & : & \text { ukuran populasi } \\
\mathrm{t} & : & \text { tingkat kepercayaan (digunakan } 0,90 \\
& & \text { sehingga nilai } \mathrm{t}=1,64) \\
\mathrm{d} & : & \text { presisi (digunakan } 0,068) \\
\mathrm{p} \quad: & \text { proporsi dari karyawan yang berkomitmen } \\
& \text { taraf dengan } 0,25 \\
\mathrm{q} & : & 1-\mathrm{p} \\
1 & : & \text { bilangan konstan }
\end{array}
$$

Hasil perhitungan maka sampel minimal yang akan diteliti dan dijadikan responden adalah sebanyak 132 orang yang terdiri dari generasi $\mathrm{X}$ dan generasi $\mathrm{Y}$ termasuk di dalam nya ada laki-laki dan perempuan.

Pengaruh kepuasan kerja (X1), Generasi (X2), jenis kelamin (X3), gaji (X4) dan pendidikan terakhir (X5) terhadap komitmen kerja (Y) di Bank Mandiri.
Model 1 menganalisis tentang pengaruh kepuasan kerja (X1), generasi (X2), jenis kelamin (X3), gaji (X4) dan pendidikan terakhir (X5) terhadap komitmen kerja (Y) di Bank Mandiri yang rangkuman hasilnya dapat dilihat pada Tabel 3. Hal ini menunjukkan bahwa sebuah model dapat dilihat baik atau tidaknya melalui beberapa indikator, yaitu nilai $\mathrm{R}$-square, nilai $\mathrm{F}$ dan nilai signifanksi.

Nilai R-square pada Tabel 3 merupakan analisis yang menunjukkan seberapa besar kontribusi variabel independen (kepuasan kerja (X1), generasi (X2), jenis kelamin (X3), gaji (X4) dan pendidikan terakhir (X5) terhadap komitmen kerja (Y). Nilai R-square adalah sebesar 0.440 , hal ini menunjukkan bahwa variasi variabel independen yang digunakan dalam model (kepuasan kerja generasi X dan Y) mampu menjelaskan sebesar $44 \%$ variasi variabel dependen (komitmen kerja). Sedangkan sisanya sebesar 56\% dipengaruhi atau dijelaskan oleh variabel lain yang tidak dimasukkan dalam model penelitian ini. Hal ini bisa disebabkan oleh faktor-faktor lain diluar dari gaji, promosi, rekan kerja, hubungan dengan penyelia dan pekerjaan itu sendiri.

Hasil pada Tabel 3 menunjukkan bahwa tidak terjadi autokorelasi pada model regresi keseluruhan karena nilai Durbin-Watson stat sebesar 1,442 berada pada nilai 0 sampai dengan 4. Dengan demikian data pada persamaan regresi tidak memiliki autokolinieritas atau terbebas dari masalah autokorelasi.

Secara simultan atau bersama-sama variabel kepuasan kerja diantaranya kepuasan dengan gaji (X1.1), kepuasan dengan promosi (X1.2), kepuasan dengan rekan sekerja (X1.3), kepuasan dengan penyelia (X1.4), 
kepuasan dengan pekerjaan itu sendiri (X1.5), generasi (X2), gender (X3), gaji (X4), dan pendidikan (X5) berpengaruh signifikan terhadap komitmen organisasi karena nilai prob (f-statistik) sebesar 0,000 lebih kecil dari $0,10(10 \%)$. Artinya, secara keseluruhan model persamaan ini layak.

Uji F pada Tabel 4 menunjukkan bahwa variabel independen (kepuasan kerja, generasi, jenis kelamin, gaji dan pendidikan terakhir) secara bersama-sama berpengaruh secara signifikan terhadap variabel dependen (komitmen kerja). Jika $\mathrm{F}$ hitung $>\mathrm{F}$ tabel maka variabel independen signifikan secara simultan terhada variabel dependen (model signifikan) atau model tidak signifikan jika $\mathrm{F}$ hitung $<\mathrm{F}$ tabel. Tabel 13 menunjukkan uji $\mathrm{F}$ hitung adalah 10,661 dan F tabel diperoleh 1,978. F tabel diperoleh menggunakan Ms. Excel dengan memasukkan tingkat keyakinan (5\%), df 1 (jumlah variabel - 1), dan df 2 (n-k-1) dengan $n$ adalah jumlah responden (132) dan $\mathrm{k}$ adalah jumlah variabel independen (5). Dari perhitungan di atas, $\mathrm{F}$ hitung $>$ F Tabel $(10,661>1,656$, hal ini berarti bahwa terdapat pengaruh secara signifikan antara kepuasan kerja, generasi, jenis kelamin, gaji dan pendidikan terakhir terhadap komitmen kerja.

Uji probabilitas juga dapat dilihat pada nilai probabilitas (sig) pada tabel 4. Pada Tabel 4 juga menunjukkan nilai probabilitas $(\mathrm{sig})=0,000$, karena nilai sig $<0,0$ maka kepuasan kerja, generasi, jenis kelamin, gaji dan pendidikan terakhir berkontirbusi secara simultan terhadap komitmen kerja.

\section{Persamaan model regresi}

Setelah melihat hasil olahan secara parsial terhadap masing-masing variabel maka kita bisa menentuka model regresi baru berdasarkan nilai konstan setiap variabel.
Komitmen $=0,735+0,485 \mathrm{X}_{1}+0,526 \mathrm{X}_{2}-0,082 \mathrm{X}_{3}-$ $0,150 \mathrm{X}_{4}-0,201 \mathrm{X}_{5}$

Secara keseluruhan model persamaan ini layak. Namun, apabila dilihat secara parsial terhadap masing-masing variabel tersebut maka kepuasan pada promosi (X1.2) dengan p-value sig sebesar 0,000 dan nilai p-value sig pada generasi (X2) sebesar 0,008 adalah yang paling berpengaruh terhadap komitmen dengan nilai sig < $0,10(10 \%)$.

\section{Generasi X Memiliki Komitmen Kerja Lebih Tinggi Berdasarkan Tingkat Kepuasan Kerja di Bank Mandiri}

Untuk melihat generasi mana yang memiliki komitmen lebih tinggi berdasarkan tingkat kepuasan kerja mereka adalah dengan melihat hasil regresi dari generasi (X2) terhadap komitmen kerja (Y).

Variabel generasi berpengaruh signifikan terhadap komitmen kerja di Bank Mandiri. Hal terbukti dengan nilai signifikansinya sebesar $0,008<0,1$ (pada taraf nyata $10 \%$ ) selain itu nilai t-hitung $>$ t-tabel, yaitu 2,706 > 1,656 (signifikan)(Tabel 5). Generasi yang paling berpengaruh terhadap komitmen adalah generasi $\mathrm{X}$. Berdasarkan metode yang digunakan generasi $\mathrm{X}$ adalah variabel dummy dengan nilai satu sedangkan generasi Y dengan nilai dummy nol. Hal ini dikatakan sebagai variabel yang paling berpengaruh karena pada generasi X nilai koefisiennya positif 0,526 . Artinya, jika hasil positif dari nilai koefisien variabel generasi sama artinya memiliki dummy nilai satu, berarti generasi tersebut yang lebih berpengaruh dari generasi lainnya.

Dengan nilai positif dari generasi $\mathrm{X}$ tersebut membuktikan bahwa generasi $\mathrm{X}$ lebih berkomitmen terhadap Bank Mandiri. Hal ini bisa digambarkan sesuai dengan karakteristik individu dan ekspektasi bekerja yang sudah dijelaskan pada Tabel 5. Dijelaskan bahwa generasi X memiliki komitmen yang tinggi baik dari jenis kelamin laki-laki dan perempuan.

Tabel 3. Hasil regresi model (X1, X2, X3, X4, X5 terhadap Y)

Model Summary ${ }^{\mathrm{b}}$

\begin{tabular}{cccccc}
\hline Model & $\mathrm{R}$ & $\mathrm{R}$ Square & Adjusted $R$ Square & Std. Error of the Estimate & Durbin-Watson \\
\hline 1 & $0,664^{\mathrm{a}}$ & 0,440 & 0,399 & 0,77527611 & 1,442 \\
\hline
\end{tabular}

a) Predictors: (Constant), Zscore(Its), Pendidikan, Zscore(Work), Generasi, Gender, Gaji, Zscore(Pay), Zscore(Spv), Zscore(Pro)

b) Dependent Variable: Zscore(Komitmen) 
Tabel 4. Hasil uji F dan signifikansi

\begin{tabular}{clccccc}
\hline \multicolumn{7}{c}{ ANOVA $^{\mathrm{b}}$} \\
\hline & Model & Sum of Squares & $\mathrm{df}$ & Mean Square & $\mathrm{F}$ & Sig. \\
\hline 1 & Regression & 57,672 & 9 & 6,408 & 10,661 & $0,000^{\mathrm{a}}$ \\
& Residual & 73,328 & 122 & 0,601 & & \\
& Total & 131,000 & 131 & & & \\
\hline
\end{tabular}

a) Predictors: (Constant), Zscore (Its), Pendidikan, Zscore (Work), Generasi, Gender, Gaji, Zscore (Pay), Zscore (Spv), Zscore (Pro)

b) Dependent Variable: Zscore (Komitmen)

Tabel 5. Hasil analisis regresi pengaruh generasi terhadap komitmen

\begin{tabular}{|c|c|c|c|c|c|c|}
\hline & \multirow{2}{*}{ Model } & \multicolumn{2}{|c|}{ Unstandardized coefficients } & \multirow{2}{*}{ 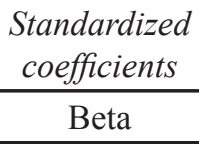 } & \multirow[t]{2}{*}{$\mathrm{t}$} & \multirow{2}{*}{ Sig. } \\
\hline & & B & Std. Error & & & \\
\hline \multirow[t]{2}{*}{1} & $($ Constant $)$ & 0,735 & 0,419 & & 1,753 & 0,082 \\
\hline & Generasi & 0,526 & 0,194 & 0,263 & 2,706 & 0,008 \\
\hline
\end{tabular}

a) Dependent Variable: Zscore (Komitmen)

Berdasarkan konsep teori dari komitmen, yaitu affective commitment, normative commitment dan continuance commitment bisa digambarkan bahwa komitmen dari generasi $\mathrm{X}$ adalah dedikasi dan kesetiaan yang dipegang untuk memenuhi tujuan organisasi dan individu sehingga bisa teralisasikan dalam bentuk tindakan.

Pada Bank Mandiri kondisi ini di alami oleh karyawan yang memiliki kepuasan kerja yang tinggi terhadap pekerjaannya yang bisa mengakibatkan kepuasan hidup mereka juga cenderung tinggi. Fenomena tentang kepuasan kerja di atas merupakan pembuktian bahwa keberadaan kepuasan kerja amat diperlukan dalam suatu perusahaan atau instansi, karena dengan terpenuhinya kepuasan kerja maka akan meningkatkan komitmen organisasi pada karyawan.

\section{Implikasi Manajerial}

Penelitian ini dapat diharapkan meningkatkan kemampuan peneliti dalam menerapkan berbagai konsep, teori, dan pendekatan gender dalam menyikapi fenomena kepuasan kerja dari kedua generasi $\mathrm{X}$ dan $\mathrm{Y}$. Bagi perusahaan yang bersangkutan agar dapat memperhatikan kebutuhan yang berbeda antara generasi X dan Y yang berkerja di Bank Mandiri. Bagi pemerintah, sebagai bahan kebijakan dalam menyikapi perubahan pola pekerja yang terjadi akibat pola pikir dan cara berkerja yang berbeda dari tiap generasi. Sehingga pemerintah mampu memperbaharui sistem kerja di setiap sektor. Bagi pembaca, menjadi bahan informasi dan bermanfaat untuk yang berminat untuk mengadakan studi lanjutan berkenaan dengan aspek gender ataupun fenomena generasi $\mathrm{X}$ dan $\mathrm{Y}$ berikutnya.

\section{KESIMPULAN DAN SARAN}

\section{Kesimpulan}

Perubahan dunia dengan teknologi mendorong terjadinya segmentasi antara satu generasi dengan generasi berikutnya. Yang secara umum bisa dibagi dalam generasi $\mathrm{X}$ dan generasi Y. Dalam bekerja generasi $\mathrm{X}$ memiliki ekspektasi kerja berdasarkan karakteristik yang dimilikinya. Alexander dan Sysko (2013) mengatakan bahwa ekspektasi bekerja dari generasi $\mathrm{X}$ adalah cenderung diberikan otoritas dalam pekerjaan hal ini disebabkan karena dalam bekerja generasi $\mathrm{X}$ tidak memiliki sifat individualis dan mampu bekerja dengan tim. Sehingga hal ini akan memberikan generasi X keterlibatan yang baik dalam pengambilan keputusan. Generasi ini cenderung akan saling mendengarkan satu sama lain karena memiliki rasa profit sharing satu sama lain sebagai rekan kerja. Sehingga pengembangan diri generasi X dilahirkan dari fasilitas dan lingkungan yang baik dalam perusahaan.

Pembahasan tentang generasi Y menjadi sangat menarik ketika dikaitkan dengan karakteristik, masalah, dan pihak yang ditemui untuk menangani masalah tersebut. Hasil penelitian ini menunjukkan karakteristik generasi Y, secara umum dapat dikatagorikan menjadi dua, yaitu karakteristik positif dan negatif. Delapan 
jenis karakteristik positif yang dimiliki generasi $\mathrm{Y}$ adalah Peduli teknologi baru, Suka mencoba-coba, aktif, memiliki kreativitas tinggi, tidak takut dengan perubahan, memiliki ide-ide brilian, pintar, dan handal. Sebaliknya, delapan jenis karakteristik negatif yang melekat pada generasi $\mathrm{Y}$ adalah individualis, mudah bosan, ego sentris, tampil beda, tidak sabar, tidak peduli, memiliki komitmen dan loyalitas rendah, dan tidak pernah serius.

Generasi Y, dengan segala karakteristik positif dan negatif yang dimiliki, memiliki berbagai masalah, yaitu adiksi gadget, tidak fokus belajar, emosi mudah terganggu, pornografi, dan pergaulan bebas. Generasi $Y$ ketika menghadapi masalah cenderung membicarakan dengan rekan sebaya dan orang tua. Anehnya, mereka ketika menghadapi masalah, tidak cenderung membicarakannya dengan konselor, psikolog, atau dosen penasehat akademik.

\section{Saran}

Para petinggi atasan Bank Mandiri perlu melakukan perubahan pendekatan dalam mengelola tenaga kerja generasi $\mathrm{X}$ untuk menghasilkan kinerja yang optimal bagi perusahaan. Menjalin komunikasi antar generasi sangat perlu dilakukan dalam suatu perusahaan Bank Mandiri. Komunikasi dapat mengurangi kesalahpahaman antar generasi dan meningkatkansosialisasi antar generasi.

\section{DAFTAR PUSTAKA}

Abbas AA, Altarawneh I. 2014. Employe engagement and organizational commitment: evidence from Jordan. International Journal of Business 19 (2).

Alexander CS, Sysko JM. 2013. Im Gen Y, I love feeling entitled and it shows. Academy of Educational Leadership Journal 174: 127-131.

Anantatmula VS, Shrivastav B. 2012. Evolution of project teams for generation $\mathrm{Y}$ worface. International Journal of Managing Projects in Business 51:9-26.

Baldonado AM, Spangenburg J. 2009. Leadership and the future: gen Y workers and two-factor theory. Journal of American Academy of Business. Cambridge 15(1):99-103.
Cholil, M. dan Riani, AS, 2003. Hubungan kepuasan kerja dan karakteristik individual dengan komitmen organisasional tenaga dosen ekonomi perguruan tinggi swasta di kota Surakarta. Jurnal Perspektif 8(1).

De Meuse, Kenneth P, Mlodzik, Kevin J. 2010. A second look at generational differences in the workforce: implication for HR and talent management. Korn/Ferry Leadership and Talent Consulting 33(2): 51-58.

Dries N, Papermans R, and De Kerpel E. 2008. Explorin four generations - beliefs about career: is satisfied the new successful. Journal of Managerial Psychology 23(8):907-28.

Fernandez PR. 2009. Impact of branding on gen Y's choice of clothing. Journal of the South East Asia Research Centre for Communications and Humanities 1(1):79-95.

Gargiulo S. 2012. Generation Y set to transform office line. CNN. Retrieved from http://www.cnn. com/2012/08/20/business/generation-y-globaloffice-culture/

Kratz H. 2013. Maximizing millennials: The who, how, and why of managing gen Y [Tesis]. United States: University of North Carolina.

Luntungan, IP. 2014. Strategi pengelolaan gen Y di industri perbankan. Jurnal Manajemen Teknologi 13(2).

Meier, Justin. 2010. Generation Y in the workforce: manageral challenges. The Journal of Human Resource and Adult Learning 6(1): 68-78.

Miller, Hodge, Brandt dan Schneider. 2014. The young and the restless: Gen Y'ers in the workplace. Are you prepared. Journal FDCC Employment Practices and Workplace Liability section 12(2):226-250.

Solnet D, Hood A. 2008. Generation Y as hospitality employees: framing a research agenda. Journal of Hospitality and Tourism Management 15: $59-68$.

Sijabat J. 2011. Pengaruh kepuasan kerja terhadap komitmen organisasi dan keinginan untuk pindah. Visi 19(3): 592-608.

Sugembong dan Sudarmoyo. 2007. Fenomena gen X dan tantangannya di tempat kerja. Proceeding Simposium Nasional ATMI 4(4):1-8.

Zemke R, Raines C, Filipczak B. 2000. Generation at Work: Managing the Clash of Veterans, boomers, Xers and Nexters in your Workplace. Ed ke2. New York: Amacom. 